International Journal of Child, Youth and Family Studies (2014) 5(1): 113-130

\title{
CHILD SEXUAL ABUSE AND YOUTH SUICIDE: A REVIEW OF THE EVIDENCE WITH IMPLICATIONS FOR FUTURE RESEARCH
}

\author{
Anne E. Rhodes, Jennifer Bethell, and Lil Tonmyr
}

\begin{abstract}
Studies of suicide and non-fatal suicide-related behaviours demonstrate a gender paradox: Suicide rates are typically higher in males than females, whereas the opposite is true for non-fatal suicide-related behaviours. However, the reasons for these differences are unclear. Among the potential explanations, particularly in youth, is the effect of child maltreatment. A previous review suggested that while child sexual abuse may be more common in girls, the negative effect may be more potent for boys (with respect to suicide attempts). However, as their risk/protective factors may not always overlap, it is unclear whether this pattern seen for suicide attempts extends to suicide. The current study reviewed the evidence for potential sex differences in the association between child sexual abuse and suicide, identified methodological challenges to such studies, and discussed implications for future theoretical formulations/testing in research. The findings confirmed that the association between child sexual abuse and youth suicide remains unclear and the potential sex differences in the association remain largely unaddressed. Further, a test of the association between child sexual abuse and suicide would be best pursued in very large, populationbased studies (with standardized measures of child sexual abuse) later linked to mortality data.
\end{abstract}

Keywords: suicide; self-injurious behavior; suicide, attempted; child abuse, sexual; child; adolescent

Acknowledgements: The Injury and Child Maltreatment Section, Health Surveillance and Epidemiology Division, Public Health Agency of Canada (PHAC) provided support for this study.

Anne E. Rhodes, Ph.D. (the corresponding author) is an Associate Professor in Department of Psychiatry and the Dalla Lana School of Public Health, University of Toronto and a Research Scientist at the Suicide Studies Research Unit, St. Michael's Hospital, 30 Bond Street, Toronto, Ontario, M5B 1W8, Canada. E-mail: rhodesa@smh.ca

Jennifer Bethell, Ph.D. is a recent graduate of the doctoral program at the Dalla Lana School of Public Health, University of Toronto and works with the Suicide Studies Research Unit, St. Michael’s Hospital, Toronto, Canada. E-mail: bethellj@shm.ca

Lil Tonmyr, MSW, Ph.D. is a senior researcher with the Injury and Child Maltreatment Section, Centre for Chronic Disease Prevention and Control, Public Health Agency (PHAC) of Canada, Ottawa, Canada. E-mail: Lil.Tonmyr@phac-aspc.gc.ca 
International Journal of Child, Youth and Family Studies (2014) 5(1): 113-130

\section{The gender paradox of suicide and non-fatal suicide-related behaviours}

In most regions of the world, the suicide rate in males is at least double that of females and the sex differential is most apparent at older ages (Krug, Dahlberg, Mercy, Zwi, \& Lozano, 2002). Conversely, non-fatal suicide-related behaviours (SRB) ${ }^{1}$ selfinflicted injury or poisoning tend to be more common in females and the sex differential lessens with age (Hawton \& Harriss, 2008). However, the reasons for these sex differences, first evident in youth, have not been thoroughly explained. As suicide rates begin to increase during the transition from childhood to adolescence, making it the second leading cause of death in 10- to 24-year-olds worldwide (World Health Organization, 2010), studies of this age group are crucial.

\section{The association between child maltreatment and suicide}

Among the potential explanations for the sex differences in SRB rates, particularly in youth, is the effect of child maltreatment. Although this area of research has been somewhat limited with respect to deciphering the unique contribution of specific forms of abuse (Joiner et al., 2007), recent evidence suggests child sexual abuse (CSA) may be a particularly potent risk factor. Bruffaerts et al. (2010) used the World Mental Health Survey (55,299 respondents aged 18 years and over in 21 countries) to study the association between nine childhood adversities (physical abuse, sexual abuse, neglect, parental death, parent divorce, other parental loss, family violence, physical illness, and financial adversity before age of 18) and lifetime suicide ideation and attempts. The study showed CSA was the strongest predictor for both ideation and attempts, in bivariate and multivariate analyses adjusting for other adversities, as well as demographic and parental psychopathology variables. Similarly, CSA has been found to predict suicide attempts among suicidal ideators, independent of other factors (Brezo et al., 2007). Further, although other studies have demonstrated the association between other forms of maltreatment and non-fatal SRB in youth, they have not always controlled for CSA (Mironova et al., 2011), even though different forms of abuse may often present together and thus bias results and limit the studies' abilities to test theories linking the abuse to outcomes (Joiner et al., 2007).

With regard to potential sex differences in the association between CSA and nonfatal SRB specifically in youth, in a previous systematic review (Rhodes et al., 2011), the relationship was found stronger in boys, and specifically for suicide attempts. Seven population-based studies provided sex-specific unadjusted estimates of the association between CSA and suicide attempt(s) and all found a statistically significant positive association in both boys and girls, but the association was stronger in boys than girls

\footnotetext{
${ }^{1}$ Suicide-related behaviours (SRB) encompass fatal and non-fatal acts, including suicides (deaths with at least some degree of suicidal intent), other self-inflicted deaths, and non-fatal self-inflicted injury or poisoning. Non-fatal SRB includes suicide attempts (where there is an intent to die from suicide) as well as acts carried out without this intent (Silverman, Berman, Sanddal, O'Carroll, \& Joiner, 2007a; Silverman, Berman, Sanddal, O'Carroll, \& Joiner, 2007b).
} 
International Journal of Child, Youth and Family Studies (2014) 5(1): 113-130

(odds ratios [ORs] from 4.5 to 30.8 and 2.2 to 5.1, respectively), including for multiple suicide attempts (ORs 11.2 and 5.0, respectively). Fewer studies provided adjusted estimates; however, these studies showed that other factors explained some, but not all, of the observed sex difference. This sex differential may reflect the nature and timing of the abuse. For example, perpetrators of abuse of boys are more likely to be same-sex (Edgardh \& Ormstad, 2000) which may be especially traumatic and isolating for these victims, also making them less likely to disclose the abuse and seek help because of shame or fear of stigmatization. Other factors may include sex differences in whether the abuse involved the use of physical force; Joiner's theory and analysis of suicidal behaviour have implicated exposure to violence in the context of abuse as key to later risk for suicidal behaviour (Joiner et al., 2007). In other words, while CSA may be more common in girls, the negative effect may somehow be stronger for boys (with respect to suicide attempts). Taken together, an implication for population attributable risk estimates may be that CSA gives rise to as many suicide attempts among boys exposed to CSA as it does among exposed girls (Rhodes et al., 2011).

Although a stronger association between CSA and suicide attempt(s) among boys compared to girls has already been reported, as their risk/protective factors may not always overlap, it is unclear whether this pattern seen for suicide attempt(s) extends to suicide. It is critical to clarify the validity of causal pathways to inform prevention efforts. Accordingly, this report will begin to assess sex differences in the association between CSA and youth suicide and discuss implications for future theoretical formulations/testing in research.

\section{The Present Investigation}

This study reviewed the empirical literature on the association between CSA and suicide in samples of youth, highlighting evidence of possible sex differences in the association, then identifying methodological challenges to such studies and discussing implications for future research.

\section{Method}

A search of published research was carried out. Studies eligible for inclusion met each of the following criteria: published between 1988 and 2011 (inclusive); reported empirical results on the estimate of CSA among suicides, and/or the association between CSA and suicide; included (but were not necessarily limited to) suicides in children, youth and young adults (up to age 25 years); and were English language. Electronic databases (including Medline, PsycINFO, and Social Services Abstracts) were searched, using subject headings "suicide" and "child abuse, sexual”, to identify relevant papers. Case reports, qualitative studies, reviews, and editorials were excluded, along with studies that examined non-fatal SRB and/or suicidal ideation (not suicide), child welfare involvement (not specified as CSA), or, suicide in CSA perpetrators (not victims). Additional papers were identified by searching references lists. Descriptive information 
International Journal of Child, Youth and Family Studies (2014) 5(1): 113-130

on the studies was abstracted and tabulated by one reviewer: type of study (psychological autopsy $^{2}$ or cohort study); information about the population studied; study characteristics (whether a control group was included and whether analyses were sex-stratified); and estimates of CSA in youth suicides (including the association with suicide). This information was reviewed and checked for accuracy by a second reviewer. Formal quality assessment rules were not applied, given the lack of consensus and evaluation tools to assess the quality of observational studies (Sanderson, Tatt, \& Higgins, 2007).

\section{Results}

The search yielded nine studies. Tables 1 and 2 provide information on the six psychological autopsy studies (Séguin, Renaud, Lesage, Robert, \& Turecki, 2011; Moskos, Olson, Halbern, Keller, \& Gray, 2005; Houston, Hawton, \& Shepperd, 2001; Appleby, Cooper, Amos, \& Faragher, 1999; Brent, Baugher, Bridge, Chen, \& Chiapetta, 1999; Brent et al., 1994) and three cohort studies (Cutajar et al., 2010; White \& Widom, 2003; Plunkett et al., 2001) that reported estimates of CSA among suicides, and/or estimates of the association between CSA and suicide. However, of these nine studies, three (Séguin et al., 2011; Brent et al., 1999; White \& Widom, 2003) did not distinguish sexual abuse from other types of abuse and maltreatment. Publication bias appears unlikely among the psychological autopsy studies, given that CSA was typically studied among an array of potential risk factors.

Overall, of these nine studies, only three reported sex-stratified results: one psychological autopsy study (Brent et al., 1999) and two cohort studies (White \& Widom, 2003; Cutajar et al., 2010). In the psychological autopsy studies, where reported, estimates of the history of CSA among suicides were about 20\% (Houston et al., 2001; Appleby et al., 1999), but ranged from less than 10\% (Brent et al., 1994) to 33\% (Moskos et al., 2005) (and no sex-specific estimates of CSA were provided). Moskos et al. (2005) found history of CSA ranged from about 5\% to 33\%, depending on the informant type (CSA was reported most often by parents). Information on the perpetrator was reported only by Houston et al. (2001), who found that of the five cases of CSA, the perpetrator was a parent in one, and for the remainder, perpetrators were friends, family friends, and strangers. Estimates of the history of CSA among suicides in the cohort studies could not be derived.

Very few psychological autopsy studies provided estimates of the association between CSA and suicide, either because there was no control group (Moskos et al., 2005; Houston et al., 2001) or because there were empty cells for the control group (Appleby et al., 1999). Of the two studies that did provide estimates of the association (Séguin et al., 2011; Brent et al., 1999), neither distinguished CSA from other types of abuse and maltreatment and both were hampered by very small numbers (especially in the control group), yielding very wide confidence intervals for effect estimates.

\footnotetext{
2 A systematic assessment of decedents' circumstances before suicide, using interviews with one or more proxy respondents (i.e., informants) (Conner et al., 2012)
} 
Estimates of the association between CSA and suicide from cohort studies varied; White and Widom (2003) showed neither a statistically significant association between maltreatment and all-cause or violent death (suicide or homicide) mortality, Plunkett et al. (2001) found the suicide rate among CSA victims was about 10 times the comparable national rate, and Cutajar et al. (2010) showed the relative risk of suicide, comparing CSA victims to controls, was 14.2 (95\% CI: 5.0-40.6) in males and 40.4 (95\% CI: 25.065.3) in females, however, subjects were followed for many years, some up until age 64.

Taken together, a history of CSA appears to be fairly common among youth who die by suicide (reported for roughly one in five). Cohort studies of CSA victims estimate suicide risk may be at least tenfold higher compared to the general population. However, it remains unclear whether the stronger association between CSA and suicide attempt(s) observed for boys compared to girls (Rhodes et al., 2011) extends to youth suicide. 
Table 1. Psychological autopsy studies of suicide that reported on sexual abuse

\begin{tabular}{|c|c|c|c|c|c|c|c|}
\hline \multirow{2}{*}{$\begin{array}{l}\text { Author, } \\
\text { year }\end{array}$} & \multicolumn{4}{|c|}{ Population (suicide cases) } & \multicolumn{2}{|c|}{ Study characteristics } & \multirow{2}{*}{$\begin{array}{l}\text { Estimate of sexual abuse } \\
\text { among suicides }\end{array}$} \\
\hline & Location & $\begin{array}{l}\text { Age } \\
\text { (years) }\end{array}$ & Source, year of death & $\begin{array}{l}\text { Response } \\
\text { rate }\end{array}$ & Control group & $\begin{array}{l}\text { Sex- } \\
\text { stratified }\end{array}$ & \\
\hline $\begin{array}{l}\text { Séguin et } \\
\text { al., } 2011\end{array}$ & $\begin{array}{l}\text { Quebec, } \\
\text { Canada }\end{array}$ & $<30$ & $\begin{array}{l}\text { Consecutive suicides } \\
\text { recorded by Quebec’s } \\
\text { Coroner's Office and } \\
\text { the Montreal Central } \\
\text { Morgue, year of death } \\
\text { not stated }\end{array}$ & $\begin{array}{l}67 \text { of } 89 \\
(75 \%)\end{array}$ & $\begin{array}{l}56 \text { living, } \\
\text { non-suicidal } \\
\text { (within the } \\
\text { previous year) } \\
\text { controls, } \\
\text { matched on } \\
\text { age, sex and } \\
\text { geographical } \\
\text { region }\end{array}$ & No & $\begin{array}{l}\text { Among suicides, sexual } \\
\text { abuse, physical or } \\
\text { psychological violence, by } \\
\text { age: age } 0-4 \text { (16\%); age 5- } \\
9 \text { (19\%); age } 10-14(18 \%) \text {, } \\
\text { and age } 15-19(16 \%) \text {. } \\
\text { OR suicide } \\
\text { (abuse/violence vs. no } \\
\text { abuse/violence), by age: } \\
10.8 \text { (95\% CI: } 1.4-86.5) \\
\text { age 0-4; } 13.2 \text { (95\% CI: } \\
1.7-104.8) \text { age 5-9; } 12.0 \\
\text { (95\% CI: 1.5-95.5) age 10- } \\
14 \text { and 9.6 (95\% CI: 1.2- } \\
77.9) \text { age } 15-19 .\end{array}$ \\
\hline $\begin{array}{l}\text { Moskos } \\
\text { et al., } \\
2005\end{array}$ & $\begin{array}{l}\text { Utah, } \\
\text { U.S.A. }\end{array}$ & $13-21$ & $\begin{array}{l}151 \text { consecutive } \\
\text { suicides recorded by } \\
\text { Utah Office of the } \\
\text { Medical Examiner, } \\
\text { 1996-98 }\end{array}$ & $\begin{array}{l}51 \text { of } 108 \\
\text { families } \\
\text { contacted } \\
(47 \%)\end{array}$ & No & No & $\begin{array}{l}\text { Sexual abuse, reported by } \\
\text { informant type: parent } \\
\text { (33\%); sibling (7\%); } \\
\text { friend (4\%); relative (7\%); } \\
\text { and, other (18\%). Note: } \\
\text { categories not mutually } \\
\text { exclusive. }\end{array}$ \\
\hline $\begin{array}{l}\text { Houston } \\
\text { et al., } \\
2001\end{array}$ & $\begin{array}{l}\text { Oxford- } \\
\text { area, } \\
\text { England }\end{array}$ & $15-24$ & $\begin{array}{l}35 \text { consecutive suicides, } \\
26 \text { undetermined deaths } \\
\text { and } 26 \text { accidental } \\
\text { deaths, recorded by }\end{array}$ & $\begin{array}{l}27 \text { of } 47 \\
(57 \%)\end{array}$ & No & No & $\begin{array}{l}\text { Sexual abuse was } \\
\text { "known" to have occurred } \\
\text { in five }(19 \%) .\end{array}$ \\
\hline
\end{tabular}




\begin{tabular}{|c|c|c|c|c|c|c|c|}
\hline & & & $\begin{array}{l}\text { seven coroners in four } \\
\text { counties ( } 40 \\
\text { undetermined and } \\
\text { accidental deaths later } \\
\text { excluded as not } \\
\text { suicides), 1993-95 }\end{array}$ & & & & \\
\hline $\begin{array}{l}\text { Appleby } \\
\text { et al., } \\
1999\end{array}$ & $\begin{array}{l}\text { Man- } \\
\text { chester, } \\
\text { England }\end{array}$ & $<35$ & $\begin{array}{l}92 \text { consecutive suicides } \\
\text { and } 53 \text { undetermined } \\
\text { deaths, recorded by four } \\
\text { coroners' courts (six } \\
\text { undetermined deaths } \\
\text { later excluded as not } \\
\text { suicides), 1995-96 }\end{array}$ & $\begin{array}{l}84 \text { of } 139 \\
\text { suicides } \\
\text { and } \\
\text { probable } \\
\text { suicides } \\
(60 \%)\end{array}$ & $\begin{array}{l}64 \text { living } \\
\text { controls, } \\
\text { matched on } \\
\text { age and sex }\end{array}$ & No & $\begin{array}{l}\text { Among suicides and } \\
\text { probable suicides, history } \\
\text { of sexual abuse was } \\
\text { reported for } 17(21 \%) \text { and } \\
\text { in none of the controls. }\end{array}$ \\
\hline $\begin{array}{l}\text { Brent et } \\
\text { al., } 1999\end{array}$ & $\begin{array}{l}\text { Western } \\
\text { Pennsyl- } \\
\text { vania, } \\
\text { U.S.A. }\end{array}$ & $13-19$ & $\begin{array}{l}\text { Consecutive suicides, } \\
\text { year of death not stated }\end{array}$ & $\begin{array}{l}140 \text { of } 194 \\
(72 \%)\end{array}$ & $\begin{array}{l}131 \text { living } \\
\text { controls, } \\
\text { obtained by } \\
\text { geographic } \\
\text { cluster } \\
\text { sampling, } \\
\text { matched on } \\
\text { age, sex, race, } \\
\text { county of } \\
\text { origin and } \\
\text { SES }\end{array}$ & Yes & $\begin{array}{l}\text { History of abuse (not } \\
\text { strictly CSA and only for a } \\
\text { subsample of the suicides } \\
\text { ( } n=75 \text { ) but all of the } \\
\text { controls). } \\
\text { RR suicide (current abuse } \\
\text { vs. no current abuse): } 16.0 \\
\text { (95\% CI: } 0.9-279.1) \text { in } \\
\text { boys and } 10.4 \text { (95\% CI: } \\
0.5-226.9) \text { in girls. } \\
\text { RR suicide (lifetime abuse } \\
\text { vs. no lifetime abuse): } 49.3 \\
\text { (95\% CI: } 6.4-377.3) \text { in } \\
\text { boys and } 11.7 \text { (95\% CI: } \\
1.1-124.8) \text { in girls. }\end{array}$ \\
\hline $\begin{array}{l}\text { Brent et } \\
\text { al., } 1994\end{array}$ & $\begin{array}{l}\text { Western } \\
\text { Pennsyl- } \\
\text { vania, }\end{array}$ & $<20$ & $\begin{array}{l}\text { Consecutive suicides, } \\
1986-90\end{array}$ & $\begin{array}{l}67 \text { of } 91 \\
(74 \%)\end{array}$ & $\begin{array}{l}67 \text { living } \\
\text { controls, } \\
\text { obtained by }\end{array}$ & No & $\begin{array}{l}\text { Among suicides, sexual } \\
\text { abuse in past year (2\%) } \\
\text { and before past year (5\%). }\end{array}$ \\
\hline
\end{tabular}


International Journal of Child, Youth and Family Studies (2014) 5(1): 113-130

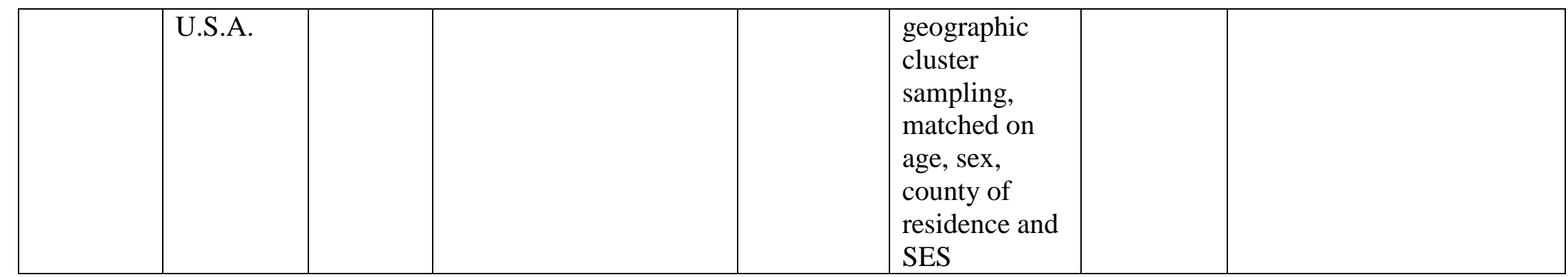

OR: Odds Ratio; SES: socioeconomic status; 95\% CI: 95\% Confidence Interval 
Table 2. Cohort studies of child sexual abuse (CSA) and suicide

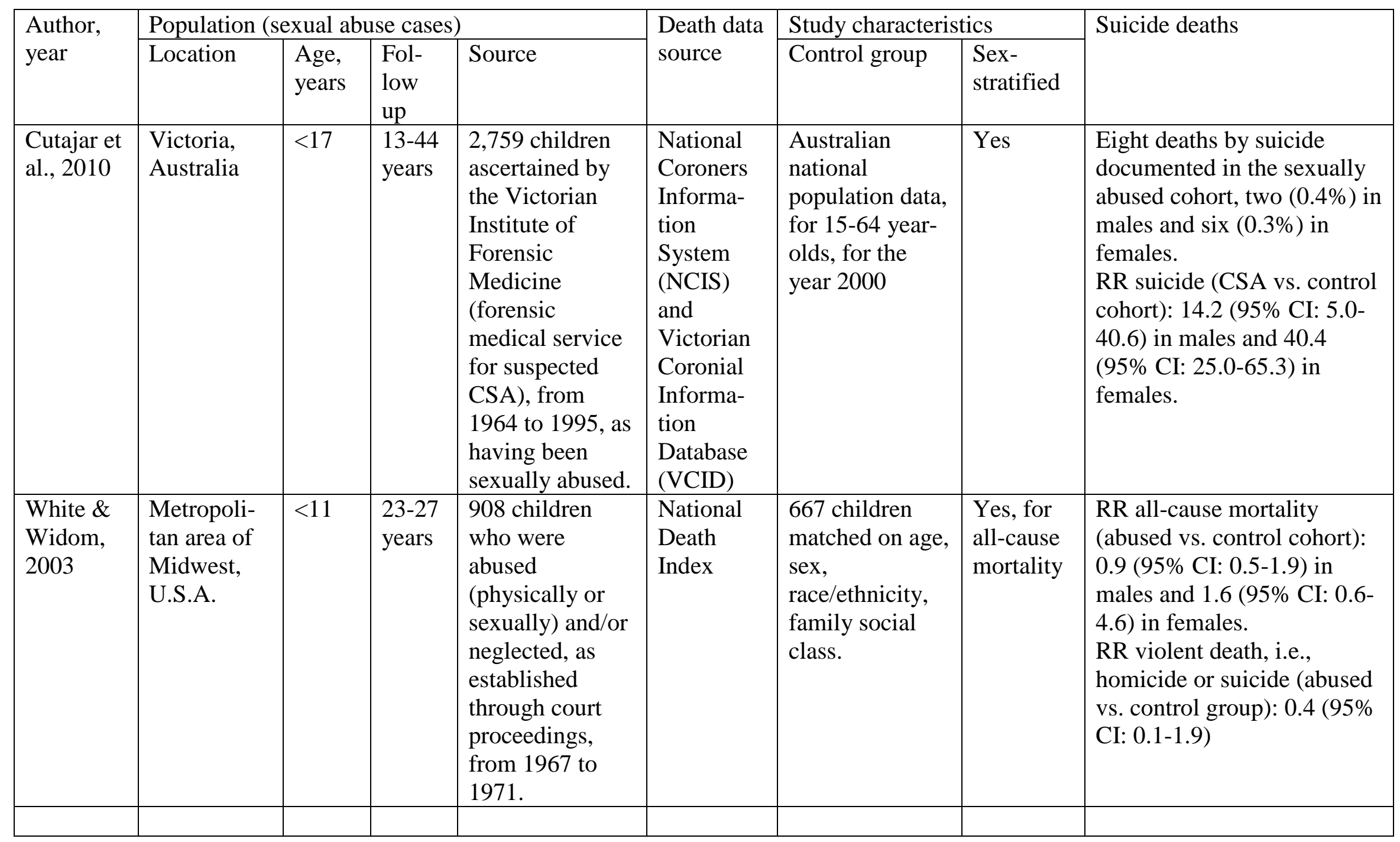




\begin{tabular}{|c|c|c|c|c|c|c|c|c|}
\hline $\begin{array}{l}\text { Plunkett } \\
\text { et al., } \\
2001\end{array}$ & $\begin{array}{l}\text { Sydney, } \\
\text { Australia }\end{array}$ & 4-15 & $\begin{array}{l}9 \\
\text { years }\end{array}$ & $\begin{array}{l}183 \text { children } \\
\text { presenting to } \\
\text { one of two } \\
\text { specialist Child } \\
\text { Protection Units } \\
\text { in Sydney in } \\
1998 \text { and } 1999 \\
\text { and confirmed } \\
\text { as sexually } \\
\text { abused. }\end{array}$ & $\begin{array}{l}\text { National } \\
\text { Death } \\
\text { Index }\end{array}$ & $\begin{array}{l}84 \text { children } \\
\text { chosen by } \\
\text { stratified } \\
\text { random } \\
\text { sampling from } \\
\text { area schools }\end{array}$ & No & $\begin{array}{l}\text { Three deaths by suicide in } \\
\text { the sexually abused cohort, } \\
\text { none among control cohort. } \\
\text { Suicide rate among abused: } \\
179 \text { per } 100,000 \text { person- } \\
\text { years (comparable national } \\
\text { suicide rate: } 13.8-16.7 \text { per } \\
100,000 \text { person-years) }\end{array}$ \\
\hline
\end{tabular}

RR: Relative Risk; 95\% CI: 95\% Confidence Interval 
International Journal of Child, Youth and Family Studies (2014) 5(1): 113-130

\section{Discussion}

This literature review demonstrated there are very few studies of the association between CSA and suicide. Accordingly, we have a poor understanding of the relationship and any potential sex differences. The few studies that have tested the association between CSA and suicide have been hampered by methodological challenges. The following section will outline these methodological challenges, by study type (as applicable).

\section{Sampling}

Psychological autopsy studies. Moskos et al. (2005) found that of the families invited to participate in the study, those who had been referred to child and protective services were less likely to participate. Given that response rates for psychological autopsy studies tended to be about 50\% to $75 \%$, this could have important implications. More specifically, this would suggest that CSA (and other forms of maltreatment) would be underestimated among youth suicides studied by psychological autopsy. It is also unclear whether this pattern of study participation also applies to controls and/or differs by sex.

Cohort studies. These studies included children and youth for whom abuse had been substantiated through medical, legal and/or social services. As such, they represented only the very small subset of abused children and youth who come to the attention of authorities (MacMillan, Jamieson, \& Walsh, 2003). Further, as discussed by Cutajar et al. (2010), these children tend to come from more "disorganized and disadvantaged families”; among children exposed to CSA, those from lower income families may be more likely to come into contact with child protection services (MacMillan et al., 2003). Children in these families likely also face other factors, aside from abuse, that might put them at increased risk for suicide (thereby possibly explaining the observed positive association). It is also unclear whether sexually abused girls are more or less likely than sexually abused boys to have their abuse substantiated through these services. Given that boys may be less likely to discuss their abuse (Hebert, Tourigny, Cyr, McDuff, \& Joly, 2009; Edgardh \& Ormstad, 2000), it seems plausible that official records capture a smaller proportion of abused boys than abused girls; in fact, MacMillan et al. (2003) showed that among children who reported CSA, girls were more likely to report contact with child protection services than boys, but the effect was not statistically significant (odds ratio 1.70, 95\% confidence interval 0.71-4.08).

\section{Misclassification}

Psychological autopsy studies. Methodological problems, including differences in measures and the number and type of informants used for each suicide, all of which vary across studies, in all likelihood affect the comparability and reliability of data from psychological autopsy studies (Pouliot \& De Leo, 2006). In fact, Moskos et al. (2005) 
International Journal of Child, Youth and Family Studies (2014) 5(1): 113-130

found that the history of CSA depended on the type of informant; CSA was frequently reported by parents (33\%), but much less often by others. CSA is highly secretive, so measurement may be particularly susceptible to misclassification either because the informant was unaware or deliberately withheld some information (Conner et al., 2012), for example, because most CSA is perpetrated by someone known to the victim, including family (Finkelhor, 1994). As such, the history of CSA is likely under-recorded among youth suicides (as well as controls), and assuming non-differential misclassification, estimates of the association between CSA and suicide are likely also underestimated (Kleinbaum, Kupper, \& Morgenstern, 1982). Furthermore, given that boys appear less likely to disclose CSA (Edgardh \& Ormstad, 2000), this misclassification may differ by sex.

Cohort studies. Although the substantiated CSA cases may be well defined in the cohort studies, control groups no doubt included some victims of CSA. For example, Cutajar et al. (2010) used national data as the control population; however, given that CSA cases were restricted to only those documented in the State of Victoria (population about 5 million), the control group would include not only the substantial proportion of CSA that goes undocumented, but also CSA victims documented in other jurisdictions. As such, the authors themselves pointed out that their study likely underestimated the association between CSA and suicide. Again, given boys may be less likely to disclose their CSA, this misclassification may differ by sex.

\section{Sample Size and Statistical Power}

Psychological autopsy studies. These studies typically do not accrue large samples because of the time and resources required to do so. As such, studying relatively rare exposures, such as CSA, may be problematic for analysis and/or yield imprecise effect estimates. For example, several studies found that none of the control group had a history of CSA and thus, in the analysis, the empty cells would have caused bias in odds ratios estimates (Agresti, 1996). This issue also restricts opportunity for sex-stratified analyses.

Cohort studies. Even assuming suicide risk is elevated among children and youth exposed to CSA, fortunately suicide is still a rare outcome and therefore, requires long follow-up and/or large samples exposed and unexposed to CSA in order to accumulate events. For example, Cutajar et al. (2010) followed a cohort of 2,759 individuals with CSA for up to 44 years, and recorded eight suicides ( $<0.5 \%$ of the cohort).

\section{Theoretical Formulations}

A better understanding of the complex association between CSA and suicide will require identifying and analyzing related factors (linked to both CSA and suicidal ideation, plans, and behaviour) (Kalucy, 2010), including mental health problems (Green, 1993), re-victimization (Balsam, Lehavot, \& Beadnell, 2011) and other risk/protective exposures during childhood (Nelson et al., 2002). As such, future studies will need to 
International Journal of Child, Youth and Family Studies (2014) 5(1): 113-130

carefully consider the roles of other variables in the association between CSA and suicide (e.g., confounder or mediator), including how to analyse them in the context of a wider hypothesized causal model (Vittinghoff, Glidden, Shiboski, \& McCulloch, 2005). For example, one study showed the association between CSA and suicide ideation and attempts was largely mediated by mental health problems and stressful life events (Fergusson, Woodward, \& Horwood, 2000). Conversely, Molnar, Berkman, and Buka (2001) found the association was only partially explained by psychiatric disorders and other childhood adversities (e.g., other forms of parental abuse). With regard to any sex differences in the association between CSA and suicide, Rhodes et al. (2011) identified possible pathways for further investigation, suggesting differential disclosure and helpseeking behaviour and recommending qualitative research, mixed methods, and more focused hypothesis testing in large, prospective observational studies.

\section{Suicides in Adulthood}

It should be noted that the cohort studies listed in the previous section extended follow-up into adulthood and therefore, may not have been studying strictly youth suicide as the outcome. In fact, Cutajar et al. (2010) found most of the suicides occurred in adulthood (mean age: 31). Accordingly, it is unclear if these relative risk estimates apply specifically to youth. Further, although we have previously reported that the association between CSA and suicide attempts may be stronger in boys than in girls, this finding may not extend to adults; results from large surveys in mainly adults have reported differing findings with regard to sex differences in the association between sexual abuse and suicide attempts (Bebbington et al., 2009; Molnar et al., 2001), suggesting substantive differences between CSA and lifetime sexual abuse and/or methodological issues including recall, disclosure, or selection bias (e.g., because of premature mortality in males). Taken together, regardless of study type, these findings reinforce the importance of carefully considering and specifying the age at which the abuse occurs and (suicide and non-fatal SRB) outcomes are studied, including the need for stratification by age as well as sex.

\section{Suicides in Childhood}

CSA appears to be associated with non-fatal SRB at a young age, perhaps even more strongly than later in life. Bruffaerts et al's analysis of World Mental Health survey data showed that history of CSA (before age 18) was associated with a tenfold increase in the odds of a suicide attempt between ages 4 and 12, but this association decreased for suicide attempts in adolescence and adulthood, with odds ratios of about 6 and 3, respectively (Bruffaerts et al., 2010). Similarly, analysis of the Netherlands Mental Health Survey and Incidence Study, with just over 7,000 adults, did not find an association between CSA and incident suicide attempts, however, additional analyses suggested this was because CSA likely results in onset of suicide attempts at a relatively young age (Enns et al., 2006). Nevertheless, there are considerable concerns in assigning a verdict of suicide to children, such as whether they communicate or understand suicidal 
International Journal of Child, Youth and Family Studies (2014) 5(1): 113-130

intent (Crepeau-Hobson, 2010). Consequently, by excluding suicides that occur among the very young, studies may not capture the full extent of the association between CSA and suicide.

\section{Conclusion}

A review of the literature confirmed that the association between CSA and youth suicide remains unclear and the potential sex difference in the association remains largely unaddressed. Studies of the association between CSA and suicide face major methodological challenges, as discussed here, underscoring inherent difficulties in addressing these questions. Some of these challenges introduce opportunities for bias, and all require careful consideration when planning for such a study, including study design and population, data sources, sample size, and length of follow-up (if applicable).

Taken together, these findings suggest that the theory regarding sex differences in the association between CSA and suicide needs further investigation. Ideally, theories could be tested in large, population-based cohorts with standardized measures of CSA, later linked to mortality data. Two such examples are population-based surveys, and, population-based child welfare registries or surveys, similar to Cutajar et al. (2010). Population-based surveys may be most promising because surveys in youth have already demonstrated sex differences in the association between CSA and suicide attempts and can capture CSA that has not been formally disclosed. Given the likely sex differential in disclosure of CSA (girls disclose more than boys), it is possible that studies based on child welfare registries or child welfare surveys would not find sex differences in the association between CSA and suicide, for example, if shame and isolation from nondisclosure were key in the causal pathway to suicide. However, to date, the surveys of youth that have addressed CSA and non-fatal SRB have been anonymous, in schoolbased settings (Rhodes et al., 2011) or collected data retrospectively from adults in order to avoid ethical issues of mandatory reporting of child abuse (Fergusson et al., 2000). The designs in the former may have precluded later linkage to mortality data, and the latter may introduce opportunities for bias (e.g., recall, disclosure, or selection). Ultimately, the need to test theoretical formulations to explain the association between CSA and suicide, and any potential sex differences therein, must be approached with an appreciation of the challenges in conducting the research and interpreting the study results. 
International Journal of Child, Youth and Family Studies (2014) 5(1): 113-130

\section{References}

Agresti, A. (1996). An introduction to categorical data analysis. New York: John Wiley \& Sons. http://dx.doi.org/10.1002/0470114754

Appleby, L., Cooper, J., Amos, T., \& Faragher, B. (1999). Psychological autopsy study of suicides by people aged under 35. British Journal of Psychiatry, 175(2), 168174. http://dx.doi.org/10.1192/bjp.175.2.168

Balsam, K. F., Lehavot, K., \& Beadnell, B. (2011). Sexual revictimization and mental health: A comparison of lesbians, gay men, and heterosexual women. Journal of Interpersonal Violence, 26(9), 1798-1814. http://dx.doi.org/10.1177/0886260510372946

Bebbington, P., Cooper, C., Minot, S., Brugha, T., Jenkins, R., Meltzer, H., et al. (2009). Suicide attempts, gender, and sexual abuse: Data from the 2000 British Psychiatric Morbidity Survey. American Journal of Psychiatry, 166(10), 11351140. http://dx.doi.org/10.1176/appi.ajp.2009.09030310

Brent, D., Perper, J., Moritz, G., Liotus, L., Schweers, J., Balach, L., et al. (1994). Familial risk factors for adolescent suicide: A case-control study. Acta Psychiatrica Scandinavica, 89(1), 52-58. http://dx.doi.org/10.1111j.1600-0447.1994.tb01485.x

Brent, D. A., Baugher, M., Bridge, J. A., Chen, T., \& Chiapetta, L. (1999). Age- and sexrelated risk factors for adolescent suicide. Journal of the American Academy of Child \& Adolescent Psychiatry, 38(12), 1497-1505. http://dx.doi.org/10.1097/00004583-199912000-00010

Brezo, J., Paris, J., Tremblay, R., Vitaro, F., Hebert, M., \& Turecki, G. (2007). Identifying correlates of suicide attempts in suicidal ideators: a population-based study. Psychological Medicine, 37(11), 1551-1562. http://dx.doi.org/10.1017/s0033291707000803

Bruffaerts, R., Demyttenaere, K., Borges, G., Haro, J. M., Chiu, W. T., Hwang, I., et al. (2010). Childhood adversities as risk factors for onset and persistence of suicidal behaviour. The British Journal of Psychiatry, 197, 20-27. http://dx.doi.org/10.1192/bjp.bp.109.074716

Conner, K. R., Beautrais, A. L., Brent, D. A., Conwell, Y., Phillips, M. R., \& Schneider, B. (2012). The next generation of psychological autopsy studies. Suicide and LifeThreatening Behavior, 42(1), 86-103. http://dx.doi.org/10.1111/j.1943-278x.2011.00073.x

Crepeau-Hobson, F. (2010). The psychological autopsy and determination of child suicides: A survey of medical examiners. Archives of Suicide Research, 14, 24 34. http://dx.doi.org/10.1080/13811110903479011

Cutajar, M., Mullen, P., Ogloff, J., Thomas, S., Wells, D., \& Spataro, J. (2010). Suicide and fatal drug overdose in child sexual abuse victims: A historical cohort study. The Medical Journal of Australia, 192(4), 184-187. 
International Journal of Child, Youth and Family Studies (2014) 5(1): 113-130

Edgardh, K., \& Ormstad, K. (2000). Prevalence and characteristics of sexual abuse in a national sample of Swedish seventeen-year-old boys and girls. Acta Paediatrica, 89(3), 310-319. http://dx.doi.org/10.1111/j.1651-2227.2000.tb01333.x

Enns, M., Cox, B., Afifi, T., De Graaf, R., Ten Have, M., \& Sareen, J. (2006). Childhood adversities and risk for suicidal ideation and attempts: a longitudinal populationbased study. Psychological Medicine, 36(12), 1769-1778. http://dx.doi.org/10.1017/s0033291706008646

Fergusson, D., Woodward, L., \& Horwood, L. (2000). Risk factors and life processes associated with the onset of suicidal behaviour during adolescence and early adulthood. Psychological Medicine, 30, 23-39. http://dx.doi.org/10.1017/s003329179900135x

Finkelhor, D. (1994). Current information on the scope and nature of child sexual abuse. Future CHild, 4, 31-53. http://dx.doi.org/10.2307/1602522

Green, A. H. (1993). Child sexual abuse: Immediate and long-term effects and intervention. Journal of the American Academy of Child \& Adolescent Psychiatry, 32(5), 890-902. http://dx.doi.org/10.1097/00004583-199309000-00002

Hawton, K., \& Harriss, L. (2008). The changing gender ratio in occurrence of deliberate self-harm across the lifecycle. Crisis: The Journal of Crisis Intervention and Suicide Prevention, 29, 4-10. http://dx.doi.org/10.1027/0227-5910.29.1.4

Hebert, M., Tourigny, M., Cyr, M., McDuff, P., \& Joly, J. (2009). Prevalence of childhood sexual abuse and timing of disclosure in a representative sample of adults from Quebec. The Canadian Journal of Psychiatry, 54(9), 631-636.

Houston, K., Hawton, K., \& Shepperd, R. (2001). Suicide in young people aged 15-24: A psychological autopsy study. Journal of Affective Disorders, 63(1/3), 159-170. http://dx.doi.org/10.1016/s0165-0327(00)00175-0

Joiner, J., Sachs-Ericsson, N. J., Wingate, L. R., Brown, J. S., Anestis, M. D., \& Selby, E. A. (2007). Childhood physical and sexual abuse and lifetime number of suicide attempts: A persistent and theoretically important relationship. Behaviour Research and Therapy, 45(3), 539-547. http://dx.doi.org/10.1016/j.brat.2006.04.007

Kalucy, R. (2010). Identifying the pathways to suicide in child sexual abuse victims. The Medical Journal of Australia, 192(4), 182-183.

Kleinbaum, D., Kupper, L., \& Morgenstern, H. (1982). Epidemiologic research. New York: Van Nostrand Reinhold.

Krug, E. G., Dahlberg, L. L., Mercy, J. A., Zwi, A. B., \& Lozano, R. (2002). World report on violence and health. Geneva: World Health Organization [Electronic version]. http://whqlibdoc.who.int/publications/2002/9241545615_eng.pdf

MacMillan, H. L., Jamieson, E., \& Walsh, C. A. (2003). Reported contact with child protection services among those reporting child physical and sexual abuse: Results from a community survey. Child Abuse \& Neglect, 27(12), 1397-1408. http://dx.doi.org/10.1016/j.chiabu.2003.06.003 
International Journal of Child, Youth and Family Studies (2014) 5(1): 113-130

Mironova, P., Rhodes, A. E., Bethell, J. M., Tonmyr, L., Boyle, M. H., Wekerle, C., et al. (2011). Childhood physical abuse and suicide-related behavior: A systematic review. Vulnerable Children and Youth Studies: An International Interdisciplinary Journal for Research, Policy and Care, 6, 1-7. http://dx.doi.org/10.1080/17450128.2010.542301

Molnar, B. E., Berkman, L., \& Buka, S. (2001). Psychopathology, childhood sexual abuse and other childhood adversities: Relative links to subsequent suicidal behaviour in the US. Psychological Medicine, 31(6), 965-977. http://dx.doi.org/10.1017/s0033291701004329

Moskos, M., Olson, L., Halbern, S., Keller, T., \& Gray, D. (2005). Utah youth suicide study: Psychological autopsy. Suicide and Life-Threatening Behavior, 35(5), 536546. http://dx.doi.org/10.1521/suli.2005.35.5.536

Nelson, E. C., Heath, A. C., Madden, P. A. F., Cooper, M. L., Dinwiddie, S. H., Bucholz, K. K., et al. (2002). Association between self-reported childhood sexual abuse and adverse psychosocial outcomes: Results from a twin study. Archives of General Psychiatry, 59, 139-145. http://dx.doi.org/10.1001/archpsyc.59.2.139

Plunkett, A., O'Toole, B., Swanston, H., Oates, R. K., Shrimpton, S., \& Parkinson, P. (2001). Suicide risk following child sexual abuse. Ambulatory Pediatrics, 1(5), 262-266. http://dx.doi.org/10.1367/1539-4409(2001)001\%3C0262:srfcsa\%3E2.0.co;2

Pouliot, L., \& De Leo, D. (2006). Critical issues in psychological autopsy studies. Suicide and Life-Threatening Behavior, 36(5), 491-510. http://dx.doi.org/10.1521/suli.2006.36.5.491

Rhodes, A. E., Boyle, M. H., Tonmyr, L., Wekerle, C., Goodman, D., Leslie, B., et al. (2011). Sex differences in childhood sexual abuse and suicide-related behaviors. Suicide and Life-Threatening Behavior, 41(3), 235-254. http://dx.doi.org/10.1111/j.1943-278x.2011.00025.x

Sanderson, S., Tatt, I. D., \& Higgins, J. P. (2007). Tools for assessing quality and susceptibility to bias in observational studies in epidemiology: A systematic review and annotated bibliography. International Journal of Epidemiology, 36(3), 666-676. http://dx.doi.org/10.1093/ije/dym018

Séguin, M., Renaud, J., Lesage, A., Robert, M., \& Turecki, G. (2011). Youth and young adult suicide: A study of life trajectory. Journal of Psychiatric Research, 45(7), 863-870. http://dx.doi.org/10.1016/j.jpsychires.2011.05.005

Silverman, M., Berman, A. L., Sanddal, N. D., O'Carroll, P. W., \& Joiner, T. E. (2007a). Rebuilding the Tower of Babel: A revised nomenclature for the study of suicide and suicidal behaviors. Part 1: Background, rationale, and methodology. Suicide and Life-Threatening Behavior, 37(3), 248-263. http://dx.doi.org/10.1521/suli.2007.37.3.248

Silverman, M. M., Berman, A. L., Sanddal, N. D., O'Carroll, P. W., \& Joiner, T. E. (2007b). Rebuilding the Tower of Babel: A Revised Nomenclature for the Study of Suicide and Suicidal Behaviors. Part 2: Suicide-Related Ideations, Communications, and Behaviors. Suicide and Life-Threatening Behavior, 37(3), 264-277. http://dx.doi.org/10.1521/suli.2007.37.3.264 
International Journal of Child, Youth and Family Studies (2014) 5(1): 113-130

Vittinghoff, E., Glidden, D., Shiboski, S., \& McCulloch, C. (2005). Regression methods in biostatistics: Linear, logistic, survival, and repeated measures models. New York: Springer.

White, H. R., \& Widom, C. S. (2003). Does childhood victimization increase the risk of early death? A 25-year prospective study. Child Abuse \& Neglect, 27(7), 841853. http://dx.doi.org/10.1016/s0145-2134(03)00110-8

World Health Organization. (2010). Suicide prevention (SUPRE). Geneva: World Health Organization [Electronic version]. Available:

http://www.who.int/mental_health/prevention/suicide/suicideprevent/en/ 